DOI 10.17805/ggz.2017.4.9

\title{
Некоторые вопросы гуманитарного сопротивления глобальному контролю масс
}

\author{
Э. Ф. МАКАРЕВИЧ \\ МОСКОВСКИЙ ГУМАНИТАРНЫЙ УНИВЕРСИТЕТ
}

\begin{abstract}
В статье идет речь о глобальном контроле масс, связанном с проблемами глобального рынка, национальной идентичности и ментальности народов. Рассматриваются возможности гуманитарного сопротивления глобальному контролю масс, что подразумевает обращение к идеям сопротивления, в конечном счете, к некой идеологии.

Ключевые слова: глобальный контроль масс; гуманитарное сопротивление; идеология; идеологическое многообразие; ценности; ценностное единство; русская классическая литература
\end{abstract}

\section{Some Issues of Humanitarian Resistance to the Global Control of the Masses}

\author{
E. F. MAKAREVICH \\ MOSCOW UNIVERSITY FOR THE HUMANITIES
}

The article deals with the global control of the masses connected with the global market, national identity and mentalities of the peoples. The author discusses the opportunities of humanitarian resistance to the global control of the masses, which implies an appeal to ideas of resistance and eventually to a certain ideology.

Keywords: global control of the masses; humanitarian resistance; ideology; ideological diversity; values; value unity; Russian classical literature

Глобальный контроль масс - это приобщение масс к демократии вообще, без учета истории, традиций, менталитета, архетипов народа. Это процесс, ведущий к утрате национальной идентичности и национальных интересов. При глобальном контроле масс цивилизационные ценности, «очищенные» от всего национального, ставятся во главу, а национальные - подавляются, коды нации и народа разлагаются, деформируется их прошлое. За ценностными конфликтами стоит диктат глобального рынка, единой мировой системы потребления товаров, услуг и продукции массовой культуры. Глобальный контроль масс - предложение массам идей и ценностей, определяемых стратегией глобализации.

Как можно сопротивляться глобальному контролю масс, который подразумевает глобальное формирование у населения разных стран определенных, как правило, унифицированных ценностей и стандартов жизни? Ведь они задаются транснациональными корпорациями и центрами культурной и политической экспансии и транслируются глобальным рынком, демократическими институтами, массовыми коммуникациями, использующими новейшие технические достижения.

Сопротивление наиболее эффективно тогда, когда оно самобытно (М. Кастельс). Самобытность сопротивления является частью культуры массовых коммуникаций и подразумевает обращение к традиционным ценностям: богу, нации, семье, к исторической памяти, к силе харизматических лидеров, способных выступать от лица массы. Это и обращение к социальным движениям, выступающим в качестве создателей и распространителей культурных кодов - образов, генетически обусловленных архетипом нации. Самобытность говорит о гуманитарном характере сопротивления гло- 
бальному контролю масс, которое определяет смыслы и образы, выражающие духовную силу народа, способного обрести свое лицо в этом мире.

В ряде случаев гуманитарное сопротивление сопоставимо с другими видами сопротивления (политическим, экономическим, демонстрационно силовым). Впрочем, гуманитарная составляющая свойственна и процессу экспансии, который и порождает, собственно, сопротивление.

Идеи для гуманитарного сопротивления рождаются благодаря научному языку. Язык - это методология познания. Если научный язык обогащается с течением времени, то возможности рождения новых смыслов преумножаются. В России в 90-е годы XX в. развитие языка социально-гуманитарного знания было искусственно прервано. После отвергнутого марксизма, не догматического, а истинного, именуемого неомарксизмом, по выражению российского философа А. В. Ахутина, общественные науки в России в определенной степени утратили свой теоретический язык, основанный не столько на рационально-инструментальном, сколько на критическом знании. Тот язык, который был совместим с западной культурой, на котором можно было творить и быть понятым западными исследователями.

Потеря языка - потеря методологии, потеря диалектического метода познания действительности. Когда это случилось в России, исследователи обратили взор на Запад. Брали все: концепции Барта, Бодрийяра, Валери, Вебера, Гэлбрейта, Аерриды, Аелёза, Аумана, Маклюэна, Маркузе, Аеви-Стросса, Парсонса, Поппера, Тоффлера, Фуко, Фрейда, Фридмана, Хайека, Ортеги-и-Гассета, Хюбнера, Ясперса. Эклектика теорий вытеснила методологию. Пришло время методологического хаоса, а в нем реАко рождаются серьезные новые смыслы.

Несмотря на идеологическое и административное давление, в СССР в социальногуманитарных науках существовали сильные научные школы (Механик, 2008). Советский Союз был одной из пяти стран мира, которые активно финансировали исторические, антропологические, лингвистические исследования. Советские научные школы античного мира и мифологии А. Ф. Аосева, диалектической философии Э. В. Ильенкова, аутентичного марксизма Г. С. Батищева, философии М. К. Мамардашвили, теории общественного сознания А. К. Уледова, психологии С. А. Рубинштейна, $\Lambda$. С. Выготского и А. Р. Аурия, психологии бессознательного А. Н. Узнадзе, семиотики Ю. М. Аотмана, М. Бахтина, массового сознания Б. А. Грушина формировали новый научный язык - язык неомарксизма. Именно глубина научных изысканий, жесткая логика научного познания позволили состояться научным школам в условиях засилья догматического марксизма и его носителей, возглавлявших научные институты и университетские кафедры. Их тоже имел в виду А. И. Солженицын, когда в 1973 г. говорил в своем «Письме вождям Советского Союза»: «Ваше заветное желание чтобы наш государственный строй и идеологическая система не менялись и стояли вот так веками. Но так в истории не бывает. Каждая система или находит путь развития, или падает» (Солженицын, 1990: 96).

В 1990-е годы место коммунистических догматиков и бюрократов в социально-гуманитарных науках заняли антикоммунистические обществоведы. Они задавили неомарксизм: одни - по недомыслию, другие - из чувства мести. Тогда-то наработанный к тому времени язык российского гуманитарного дискурса был уничтожен.

Теперь отечественное обществознание пытается найти себя по большей части в колее западного знания. Как вопль отчаяния прозвучал призыв высшей PR-власти, ответственной за имидж России, к российским обществоведам: «Надо пытаться выйти 
за пределы той ниши, которую нам отвела чужая речь... Тот, кто говорит, тот формирует реальность... Как только у России появится собственная предъява, появится и дискурс... Это же катастрофа... когда мы не участвуем даже в игре, когда нас нет, мы ничего не предлагаем?..» (Цит. по: Кригер, 2008).

Все же российские интеллектуалы из неомарксистов попытались сформулировать и предъявить миру свою идею. Сопротивляясь политической экспансии Запада, Россия провозгласила идею суверенной демократии.

Впервые объяснение этого понятия появилось в работах А. С. Панарина, который писал, что Америкой «последовательно отвергается ключевое для демократии понятие политического суверенитета народа». Аело в том, что «там, где имеет место такой суверенитет, национальные интересы по определению не могут быть предметом купли-продажи» (Панарин, 2006: 23).

Начиная с середины 2004 г. понятие суверенной демократии стало встречаться в выступлениях и публикациях политиков и политологов, превратившись в определенную политическую концепцию. В их интерпретации суверенная демократия это такой образ политической жизни общества, при котором власти, их органы и действия выбираются, формируются и направляются исключительно российской нацией на основе национальных интересов. По их мнению, существует угроза превращения России либо в придаток транснациональных корпораций, либо в закрытое общество.

Этой угрозе и противопоставлена концепция суверенной демократии: «Суверендемократический проект относится к числу допускающих будущее, и не какоенибудь, но отчетливо национальное. Мы обязаны выстроить базис инновационной культуры, системы создания уникальных знаний, поскольку знание - это власть и капитал для сбережения народа. Мы обязаны конвертировать сырьевую экономику в интеллектуальную, чтобы проложить России путь в будущее, в сообщество креативных наций, направляющих историю» (Сурков, 2006).

Но развитие страны в условиях глобализации не может определяться только идеей сопротивления. Вместе с ней энергетику развития должна задавать идея экспансии, которая также служит разрешению основного противоречия эпохи - между глобализацией и суверенитетом.

Какая политико-философская концепция выражает идею экспансии современной России? В разработках российского внешнеполитического ведомства она выглядит так: во внешней политике «не будет друзей и врагов, а будут только интересы» (Гаазе, Зыгарь, 2010: 13). Исходя из этого принципа, важно установить взаимодействие между национальными интересами и суверенной демократией. Национальные интересы не могут быть предметом купли-продажи (А. Панарин). Если они станут продаваться, падение суверенной демократии неизбежно.

Каким же образом можно сохранить и развивать национальные интересы и суверенную демократию в современном мире? Аипломаты предлагают такое решение этой задачи: в интересах России важно «укрепление отношений взаимозависимости с ведущими мировыми державами на основе взаимопроникновения экономик и культур» (Гаазе, Зыгарь, 2010: 13). Взаимопроникновение экономик и культур - вот что позволит удержаться в поле сопротивления политическому и культурному поглощению. Принцип «только интересы» предлагает и определенную практику - партнерство с иностранными инвесторами, готовыми инвестировать в России и развивать вместе с российским бизнесом совместные проекты, в том числе и мирового уровня. При та- 
ком варианте развития событий экспансия рассматривается и как сопротивление глобальному поглощению.

Россия определяет свой путь экономического роста медленно, оглядываясь то на идею суверенной демократии, то на идею глобализации интересов и выгоды. Но у нее нет образов «опредмеченной перспективы», нет цивилизационного проекта на основе определенных идей и ценностей. Аа и выведут ли страну на новую орбиту идея суверенной демократии и принцип «только интересы»? Нужны смыслы духовные, нужна интеллектуальная работа, способная их сотворить.

Поэтому так оказалась востребована необходимость идеологии, способной определить проект развития страны. Идеология как совокупность идей - изменчивая субстанция, зависящая от интересов классов и социальных групп, от времени, в котором в данный момент живет страна, от глобального мира. В поисках идеи надежнее обратиться к нравственным ценностям, которые порождены мировой и отечественной культурой, и не носят краткого временного и тактического характера как идеология политических идей и взглядов, именуемая, по словам классиков марксизма, «ложным сознанием». Идеология как духовная культура - более надежная и существенная категория в пространстве и времени.

Теория становится материальной силой, как только она овладевает массами, - говорил классик, подразумевая идеологию. Овладев массами, идеология становится движущей силой изменений. Соглашаясь с этим, надо согласиться и с тем, что идеология овладевает массами и «ведет» их в том случае, если есть определенная идеологическая программа действий, принятая большинством людей. Тогда появляется социальный «цемент», сплачивающий их.

Но может ли этот «цемент» появиться, когда провозглашено идеологическое многообразие? Статья 13 Конституции РФ об этом. Несомненно, идеологическое многообразие превращает «цемент» в «песок». И тогда выход в том, чтобы выстроить идеологию на платформе ценностей, воспринимаемых подавляющей массой людей. Ценности как некие сущности (предметы, явления), выбранные людьми, сущности, удовлетворяющие жизненные потребности человека, класса, общества, - способны «цементировать» массу, имея «высокое звучание» и всеобщий характер.

Бессмысленно рассуждать о ценностях как таковых без обращения к человеку. Ценности всегда «завязаны»на человека, в отличие от идей, которые более связаны с интересами классов и социальных групп. Интересно, что В. И. Аенин в своей первой публичной речи после гражданской войны в России, речи, обращенной к молодежи, говорил не о коммунистических идеях, а о ценностях: о знании как ценности, о морали и нравственности как ценности; о справедливости как ценности, о самодеятельности и инициативе молодежи как ценности.

В начале 90-х годов XX в. американские исследователи констатировали, что в президентских кампаниях в США на первое место должен быть вынесен ценностный фактор. Они писали: «Президентские выборы всегда касаются ценностей. ... 2000 г. был о ценностях, 1996 г. был о ценностях, 1992 г. был о ценностях. Президентские выборы всегда о ценностях. Проблемы, личности и другие подобные вещи не являются решающими в президентских выборах. Эти вещи являются индикаторами того, что говорить людям о ценностях...» (Electing the president, 2006: 25).

Идеология, выработанная через критическое знание, может быть представлена не столько суммой политических идей, имеющих тактический характер, сколько социально-экономическими, политическими и нравственными ценностями, «строящими» 
идею, которую люди воспринимают как свою. Это ценности честного труда и знаний, выработанных культурой; это ценности социальной справедливости, свободы и демократии, совести и гражданской ответственности, добра и милосердия, семьи и уважения к человеку и его развитию как высшей ценности.

Человек, попадая в идеологическую систему зависимых интегральных ценностей, духовно откликается на нее и пытается стать их носителем. По сути, эта модель взята от христианства, в котором человек вырабатывает свою жизненную позицию на основе христианских добродетелей. Все эти ценности, так или иначе, носят нравственный оттенок. Нравственная ценность приобретает всеобщий характер в отличие от социальной и политической идеи, но она может отражать эту идею, и становиться всеобщей для всех. Тогда уже не работает подход «идеологического многообразия». И выбор большинства будет предопределен непротиворечивостью ценностей.

Если рассматривать идеологию как совокупность ценностей, выражающих интересы человека, определенных социальных групп, то тогда она способна интерпретировать социальную реальность через призму этих ценностей, и задать программу практических действий, разделяемых обществом. Ценности честного труда и знаний, выработанных культурой; ценности социальной справедливости, совести и гражданской ответственности, свободы человека, выраженной в его самодеятельности, демократии жизненного пространства человека; ценности добра и милосердия; семьи и уважения к человеку и его развитию как высшей ценности, - это ценностное единство, ориентированное по вектору главной нравственной силы - патриотизма. И она может овладеть массами при политической воле власти.

Именно за такую патриотическую идеологию ценностей выступал великий русский писатель Антон Павлович Чехов. В 1890 г. он пишет своему издателю: «Мы, говорят в газетах, любим нашу великую родину, но в чем выражается эта любовь? Вместо знаний - нахальство и самомнение паче меры, вместо труда - лень и свинство, справедливости нет, понятие о чести не идет дальше «чести мундира», мундира, который служит обыденным украшением наших скамей для подсудимых» (Чехов, 2010: 311-312).

Чеховский концепт как ценностная формула патриотизма (знание, труд, справедливость, честь), как идеология ценностного единства, может стать единой для всего общества. Но при условии того, что и свобода как ценность тоже найдет свое место в идеологии ценностного единства, И здесь обнаружится синергетический эффект взаимодействия духовной культуры и идеологии, порождающий идеологию ценностей.

Россия сильна классической литературой, поднимающей такой пласт вопросов, который и сегодня влияет на развитие философских и политических наук. Русская классическая литература, публицистика великих русских писателей, школа литературоведения и критики, в которых сохранились литературный и теоретический языки, подсказывают области исследования, где могут появиться новые смыслы, способные преобразоваться в новые образы. Предрасполагает к этому прежде всего творчество А. С. Пушкина, Н. В. Гоголя, И. С. Тургенева, Ф. М. Аостоевского, А. Н. Толстого, А. П. Чехова, обращенное к проблеме человека.

Вслед за концепцией Чехова можно выдвинуть концепцию Н. В. Гоголя, которая приобретает неожиданную остроту и динамику в нынешних условиях: «Русская история только со времени последнего ее направления при императорах приобретает яркую живость; до этого характер народа большею частию был бесцветен, разнообразие страстей ему мало было известно» (Гоголь, 1981: 243). Выходит, империя как цивили- 
зация дает и задает простор творчеству русского человека? Империя дает и задает энергетику движения человеку, энергетикой и волей имперской преодолевая леность и инерционность характера русского.

И, как отмечал И. С. Тургенев: будем надеяться, что всякий наш потомок «докажет, что он, подобно Пушкину, стал более русским и более образованным, более свободным человеком!» (Тургенев, 1981: 253). Это и есть имперский прогресс личности: стать более русским, более образованным, более свободным.

Общественному прогрессу, движимому ценностями европейской цивилизации, совершенно не чужда формулировка К. Маркса и Ф. Энгельса: «Свободное развитие каждого является условием свободного развития всех» (Маркс, Энгельс, 1983: 127).

\section{СПИСОК АИТЕРАТУРЫ}

Гаазе, К., Зыгарь, М. (2010) Пусть опять будет солнце // Русский Newsweek. 11-16 мая.

Гоголь, Н. В. (1981) Несколько слов о Пушкине // Пушкин А. С. Собр. соч. : в 10 т. М. : Правда. T. $10.447 \mathrm{c}$.

Кригер, И. (2008) Апрельские тезисы Владислава Суркова // Новая газета. № 31.

Маркс, К., Энгельс, Ф. (1983) Избр. произв. : в 3 т. М. : Политиздат. Т. 1. 635 с.

Механик, А. (2008) Мы живем под собою не чуя страны // Эксперт. № 34.

Панарин, А. С. (2006) Народ без элиты. М. : Алгоритм. 352 с.

Солженицын, А. И. (1990) Письмо вождям Советского Союза // Диалог. № 4. 112 с.

Сурков, В. Ю. (2006) Национализация будущего: параграфы pro суверенную демократию // Эксперт. № 43.

Тургенев, И. С. (1981) Речь по поводу открытия памятника А. Пушкину // Пушкин А. С. Собр. соч. : в 10 т. М. : Правда. Т. 10.447 c.

Чехов, А. П. (2010) Собр. соч. : в 15 т. М. : Книжный клуб «Книговек». Т. 14. Из записных книжек. 1877-1891. 384 c.

Electing the president, 2004: The insider's view (2006) / ed. by K. H. Jamieson. Philadelphia : University of Pennsylvania Press. viii, $251 \mathrm{p}$.

Аата поступления: 27.07.2017 2.

Макаревич Эдуард Федорович - доктор социологических наук, профессор кафедры философии, культурологии и политологии Московского гуманитарного университета. Адрес: 111395, Россия, г. Москва, ул. Юности, 5. Тел.: +7 (499) 374-55-11. Эл. aдpec: edward.makarevich@mail.ru

Makarevich Eduard Fyodorovich, Doctor of Sociology, Professor, Department of Philosophy, Culturology and Politology, Moscow University for the Humanities. Postal address: 5 Yunosti St., 111395 Moscow, Russian Federation. Tel.: +7 (499) 374-55-11. E-mail: edward.makarevich@mail.ru

\section{Аля читтирования:}

Макаревич Э. Ф. Некоторые вопросы гуманитарного сопротивления глобальному контролю масс [Электронный ресурс] // Горизонты гуманитарного знания. 2017, №4. URL: http://journals. mosgu.ru/ggz/article/view/584 (дата обращения: дА.мм.гггг.). DOI: 10.17805/ggz.2017.4.9 